\title{
PENERAPAN KONSEP ZERO WASTE DALAM USAHA PENGGEMUKAN SAPI: UPAYA UNTUK MENINGKATKAN NILAI EKONOMI LIMBAH TERNAK
}

\author{
Rupa Matheus*, Jemseng C. Abineno* dan Antonius Jehamat* \\ *Jurusan Manajemen Pertanian Lahan Kering, Politeknik Pertanian Negeri Kupang \\ e-mail : matheusrupa@yahoo.com
}

\begin{abstract}
ABSTRAK
Salah satu jenis usaha ternak dikalangan masyarakat Amarasi wilayah Kabupaten Kupang adalah usaha penggemukan sapi yang dalam bahasa lokal disebut sistem "paron". Sistem paron merupakan pola penggemukan ternak sapi khusus ternak sapi jantan yang ditujukan sebagai tabungan keluarga, untuk memenuhi kebutuhan finansial (uang tunai) yang mendadak seperti untuk pendidikan, kesehatan anak dan keluarga. Model atau sistem penggemukan sapi, oleh masyarakat Amarasi belum ditangani secara baik, masih bersifat tradisional, dan belum ada sentuhan teknologi apapun. Untuk mengatasi permasalahan tersebut, perlu adanya terobosan melalui penerapan teknologi tepat guna, yaitu memperbaiki penggemukan (sistem paron) dan menerapkan konsep zero waste sebagai upaya dalam penanganan limbah untuk mendukung kemandirian energi di pedesaan. Pendekatan yang digunakan dalam program Desiminasi Produk Teknologi ke Masyarakat (DPTM) ini adalah melalui pelatihan dan pendampingan mitra sasaran, sehingga terjadi perubahan perilaku mitra dalam mengelola usaha penggemukan (paron) sapi dan memandang limbah ternak sebagai potensi yang memiliki nilai tambah secara ekonomis untuk dikembangkan. Hasil kegiatan DPTM yang dilakukan selama enam bulan (Juni sampai dengan November 2019), menunjukkan bahwa program ini memberikan dampak positip terhadap perubahan perilaku petani dan pola usahatani ramah lingkungan. Melalui program ini mitra sasaran dapat mengolah limbah / kotoran ternak sapi menjadi biogas dan pupuk organik (padat dan cair)
\end{abstract}

Kata Kunci: Kosep pertanian zero waste, usaha penggemukan sapi, nilai ekonomi limbah 


\section{PENDAHULUAN}

Wilayah Timor, Nusa Tenggara Timur (NTT), merupakan salah satu wilayah di Indonesia yang memiliki potensi dalam pengembangan ternak sapi, sehingga wilayah ini dijuluki sebagai salah satu gudang ternak sapi bali di Indonesia. Salah satu wilayah Timor yang cukup terkenal dengan usaha ternak sapi adalah wilayah Amarasi. Wilayah ini memiliki potensi peternakan sapi yang paling banyak, karena dukungan areal yang luas dan ketersediaan pakan ternak yang cukup.

Rata-rata setiap rumah tangga petani minimal memiliki 2-3 ekor ternak sapi. Usaha penggemukan ternak sapi di wilayah Amarasi ini, cukup spesifik sehingga dikenal dengan sebutan lokal sebagai "sistem paron". Sistem "paron” merupakan salah satu model atau sistem penggemukan ternak khusus sapi jantan yang dilakukan secara semi intensif dengan cara diikat dalam areal kebun yang sudah dipersiapkan hijauan pakannya (Matheus et al, 2019). Sistem paron ini dilakukan secara berkelompok pada satu titik dengan jumlah ternak antara 5-10 ekor. Caranya ternak diikat di bawah naungan pohon, dan diberi pakan hijauan secara rutin. Hijauan pakan utama adalah Lamtoro (Lеисаеna). Sistem paron yang dijalankan oleh kelompok mitra, seperti terlihat pada Gambar 1

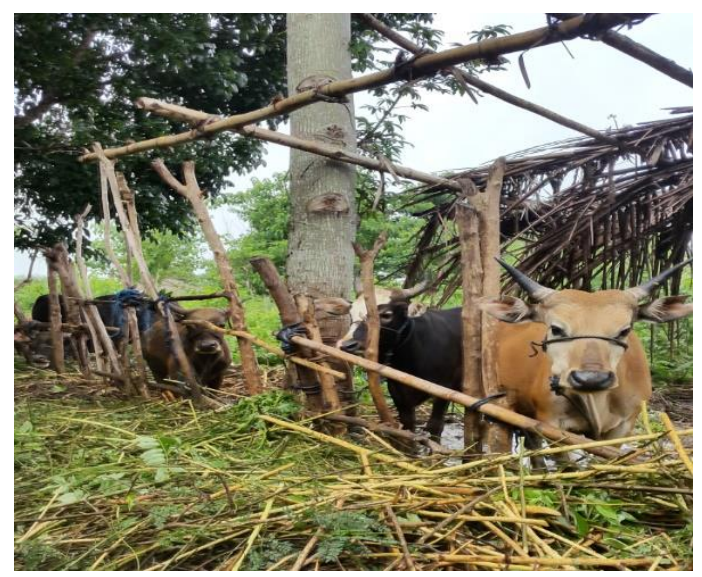

Gambar 1. Sistem paron sapi oleh masyarakat Amarasi

Permasalahan utama dari sistem paron ini, adalah masa paron (penggemukan) relatif lama, yaitu antara 1-2 tahun tergantung dari bobot awal ternak sapi yang akan digemukan, peningkatan bobot badan ternak relatif kecil, rata-rata antara 0,3-0,5 kg/hari). Artinya dengan masa penggemukan selama 12 bulan, hanya terjadi kenaikan bobot badan sebesar 108 kg/ekor - 180 kg/ekor, ternak kurang sehat dan pertumbuhan lambat (karena kehujanan, kepanasan dan hidup di atas tumpukan 
kotoran), banyak pakan yang terbuang, menimbulkan bau (pencemaran) akibat kotoran dan sisa pakan yang berserakan; limbah ternak (feses dan sisa pakan di biarkan begitu saja, tanpa adanya upaya pengolahan lebih lanjut.

Memperhatikan permasalahan dan kondisi usahatani yang dilakukan oleh kelompok mitra, maka perlu adanya terobosan melalui desiminasi produk teknologi ke masyaraat (DPTM) sebagai solusi untuk meningkatkan kemandirian petani mitra. Solusinya adalah memperbaiki sistem paron sapi dan menerapkan teknologi penanganan limbah untuk meningkatkan nilai tambah dari sistem paron tersebut (Anonimous, 2008). Produk teknologi yang didesiminasikan ke masyarakat (PTDM) adalah "penerapan konsep zero waste pada usaha penggemukan sapi". Pilihan pada konsep pertanian zero waste adalah suatu upaya untuk memberikan nilai tambah pada limbah ternak yang dihasilkan (Yuwono dkk, 2013, Matheus dkk, 2019). Melalui perbaikan sistem pemeliharaan akan mendapatkan jumlah limbah yang melimpah. Karena kotoran ternak merupakan komponen terbesar dari usaha penggemukan sapi. Jika limbah ternak ini tidak ditangani dapat menimbulkan masalah masalah lingkungan (Yuwono dkk, 2013), di satu pihak limbah ternak juga juga menyimpan peluang pemanfaatan yang potensial (Widjayanto and Miyauchi, 2003; Sudiarto, 2008). Harapannya melalui program ini nantinya akan terciptanya usaha produktif, berupa pemanfaatan dan produksi pupuk dari limbah ternak yang dikelola oleh kelompok mitra secara mandiri.

\section{METODE PELAKSANAAN KEGIATAN}

Program DPTM dilaksanakan untuk membantu mengatasi masalah produktivitas usaha penggemukan sapi yang dihadapi oleh petani/peternak yang tergabung dalam Kelompok tani ternak Ponaen Lestari di Desa Ponaen, Kecamatan Amarasi, Kabupaten Kupang. Kegiatan ini berlangsung selama 6 (enam bulan), yaitu dari bulan Juni s/d November 2019.

Metode pelaksanaan program DPTM ini dilakukan dengan pendekatan Participatory Action Programs dimana petani mitra yang terlibat dalam program ini secara langsung mengikuti dan menerapkan berbagai ketrampilan yang telah diajarkan. Prosedur kegiatan PTDM dilakukan melalui beberapa tahapan, yaitu: (a) sosialisasi, (b) tahap pelatihan ketrampilan teknologi zero waste pada usaha penggemukan sapi, (c) tahap penerapan teknologi zero waste untuk menghasilakn produk teknologi yang menjadi target luaran, (d) tahap pendampingan, serta (e) 
tahap pemanfaatan produk teknologi yang dihasilkan, berupa pupuk dan biogas. Secara garis besar model desiminasi teknologi dilaksanakan seperti pada Gambar 2.

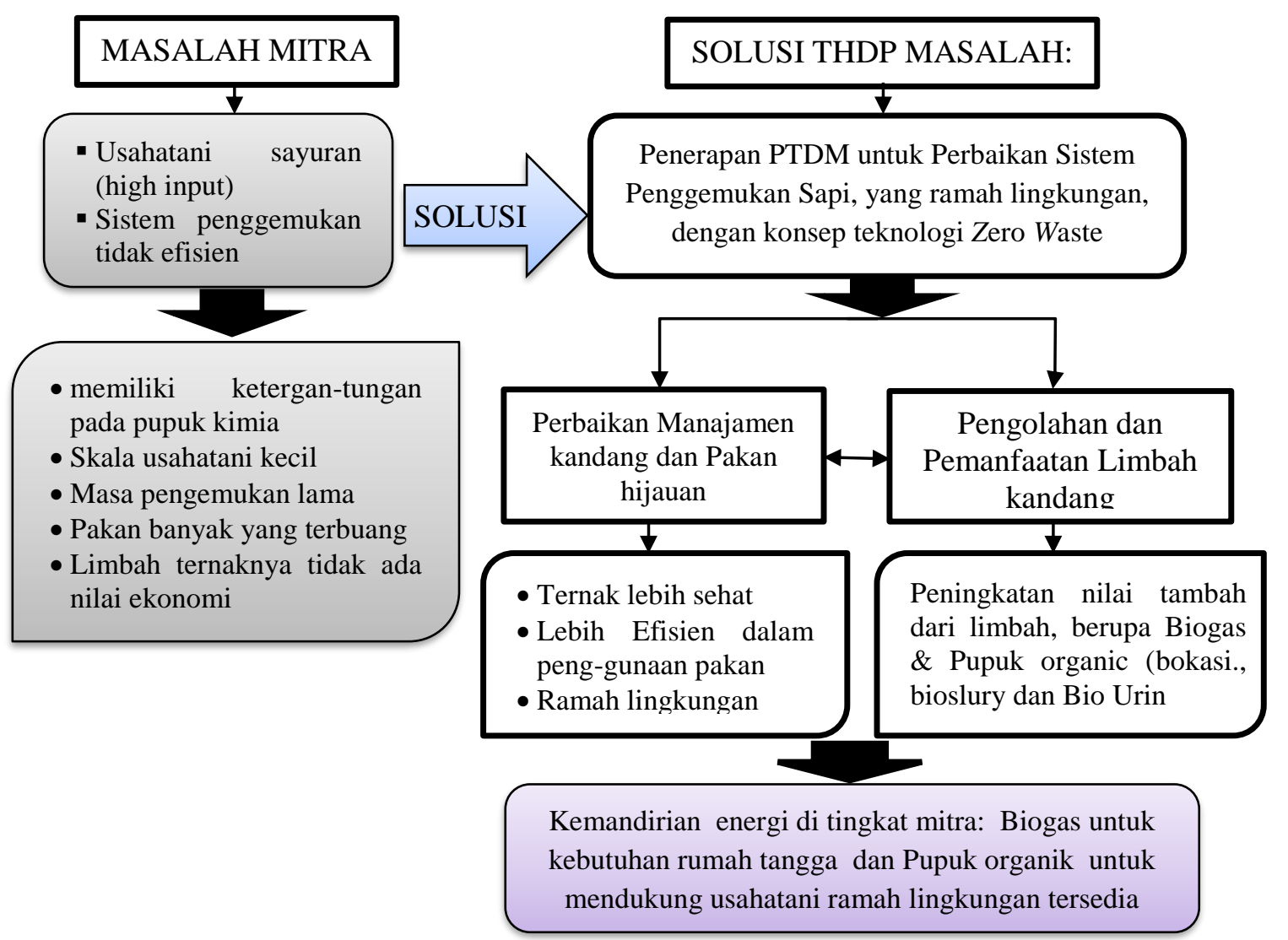

Gambar 2. Skema solusi penerapan teknologi tepat guna untuk mengatasi permasalahan mitra usaha penggemukan sapi

\section{HASIL KEGIATAN YANG DICAPAI}

\section{Deskripsi Teknologi yang Didesiminasikan}

Secara ringkas model diagram teknologi zero waste yang diterapkan pada kelompok mitra adalah sebagai berikut:

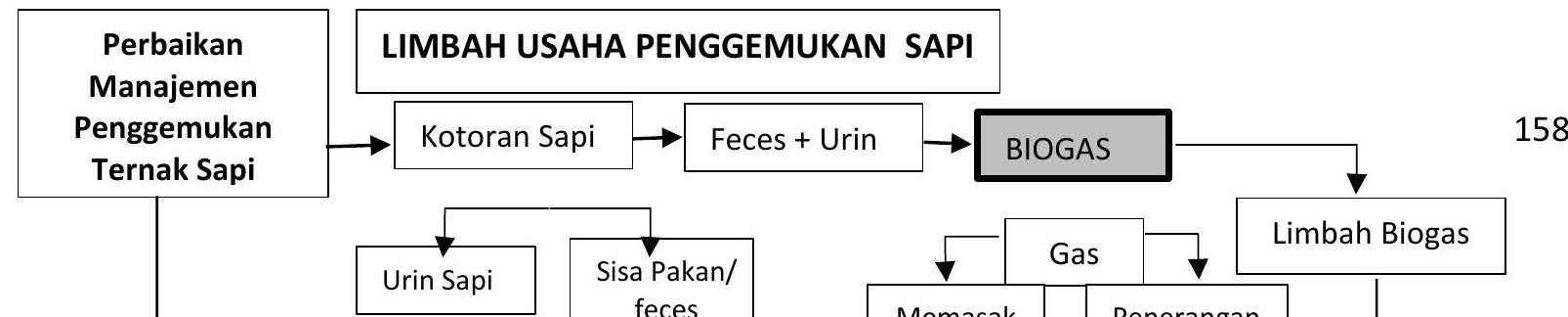


Gambar 3. Model diagram desiminasi konsep zero waste dalam usaha penggemukan Sapi pada Mitra Sasaran

Model diagram desiminasi konsep zero waste, seperti yang digambarkan di atas, secara umum memiliki karakteristik yang sederhana dan mudah diterapkan oleh petani mitra. Melalui konsep zero waste ini, telah terkaji perubahan pola pikir kelompok mitra, yang semula memandang limbah ternak sebagai masalah polusi, kini mereka telah memandang limbah ternak sebagai potensi yang memiliki nilai ekonomis. Produk teknologi utama yang dihasilkan dari program DPTM ini adalah teknologi biogas dan teknologi pupuk organic. Produk teknologi ini dihasilkan dari manajemen limbah ternak sapi.

\section{Dampak Program Terhadap Perubahan Perilaku Petani-Peternak Mitra Sasaran}

Upaya untuk meningkatkan pengetahuan dan sikap petani mitra terhadap konsep zero waste pada usaha penggemukan sapi, dilakukan melalui tiga tahap kegiatan yaitu pelatihan ketrampilan, pembuatan demplot dan pendampingan mitra sasaran. Pelaksanaan kegiatan pelatihan dilakukan di Aula Kantor Kepala Desa Ponaen kacamatan Amarasi, dengan menghadirkan beberapa nara sumber, yaitu Camat Amarasi, dan Kepala Pusat P2M Politani Negeri Kupang dan tim pelaksana. Tujuannya untuk memberikan pemahaman kepada petani mitra sasaran akan potensi dan pentingnya mengolah serta memanfaatkan limbah ternak sapi menjadi produk yang bernilai ekonomi. Harapannya akan terjadi perubahan pola pikir petani mitra sasaran. 
Hasil yang dicapai pada tahap kegiatan pelatihan ini adalah masyarakat khususnya kelompok petani mitra telah memiliki pengetahuan dan wawasan yang baik tentang konsep zero waste dalam pemanfaatan limbah ternak sapi menjadi energy baru untuk menunjang kegiatan usahataninya. Dokumentasi penyuluhan dan pelatihan terlihat pada Gambar 4 berikut.

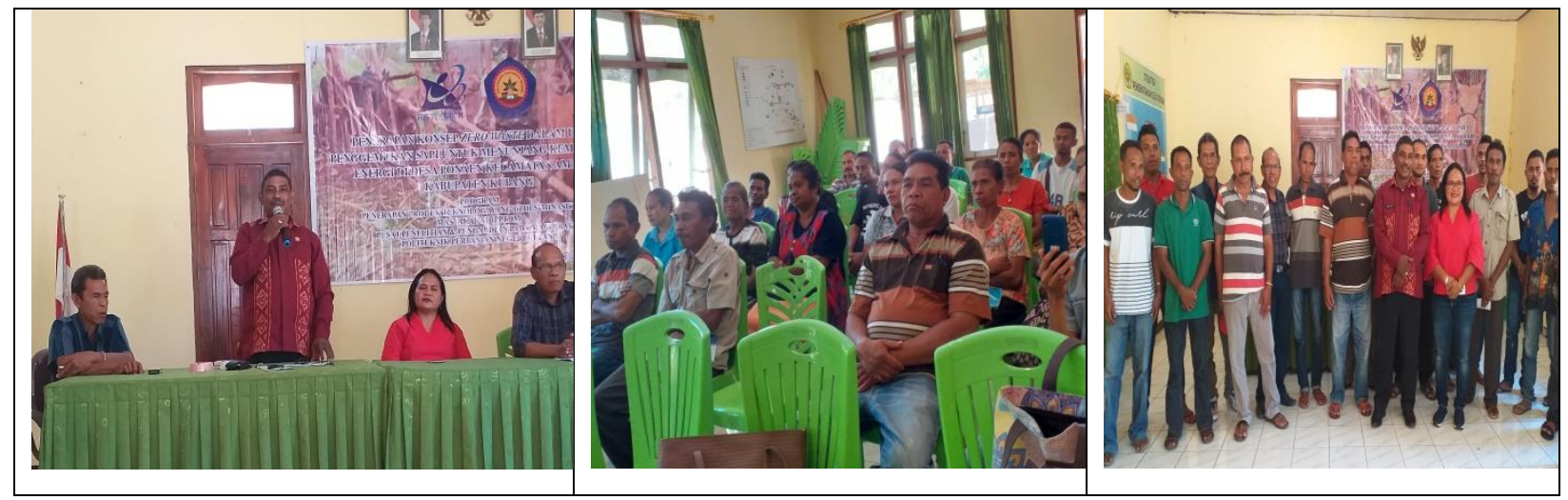

Gambar 4. Kegiatan pelatihan Ketrampilan bagi Petani mitra

Setelah pelaksanaan pelatihan dilanjutkan dengan pembuatan demplot yang dilaksanakan oleh tim pelaksana bersama dengan kelompok mitra. Proses pelaksanaan demplot dilakukan dalam bentuk perbaikan sistem perkandangan, manajemen pakan dan praktek instalasi biogas serta praktek pembuatan pupuk organik padat dan cair dari limbah ternak sapi (feses dan urin) dan dari bahanbahan yang lain yang mudah diperoleh, didampingi oleh tim pelaksana.

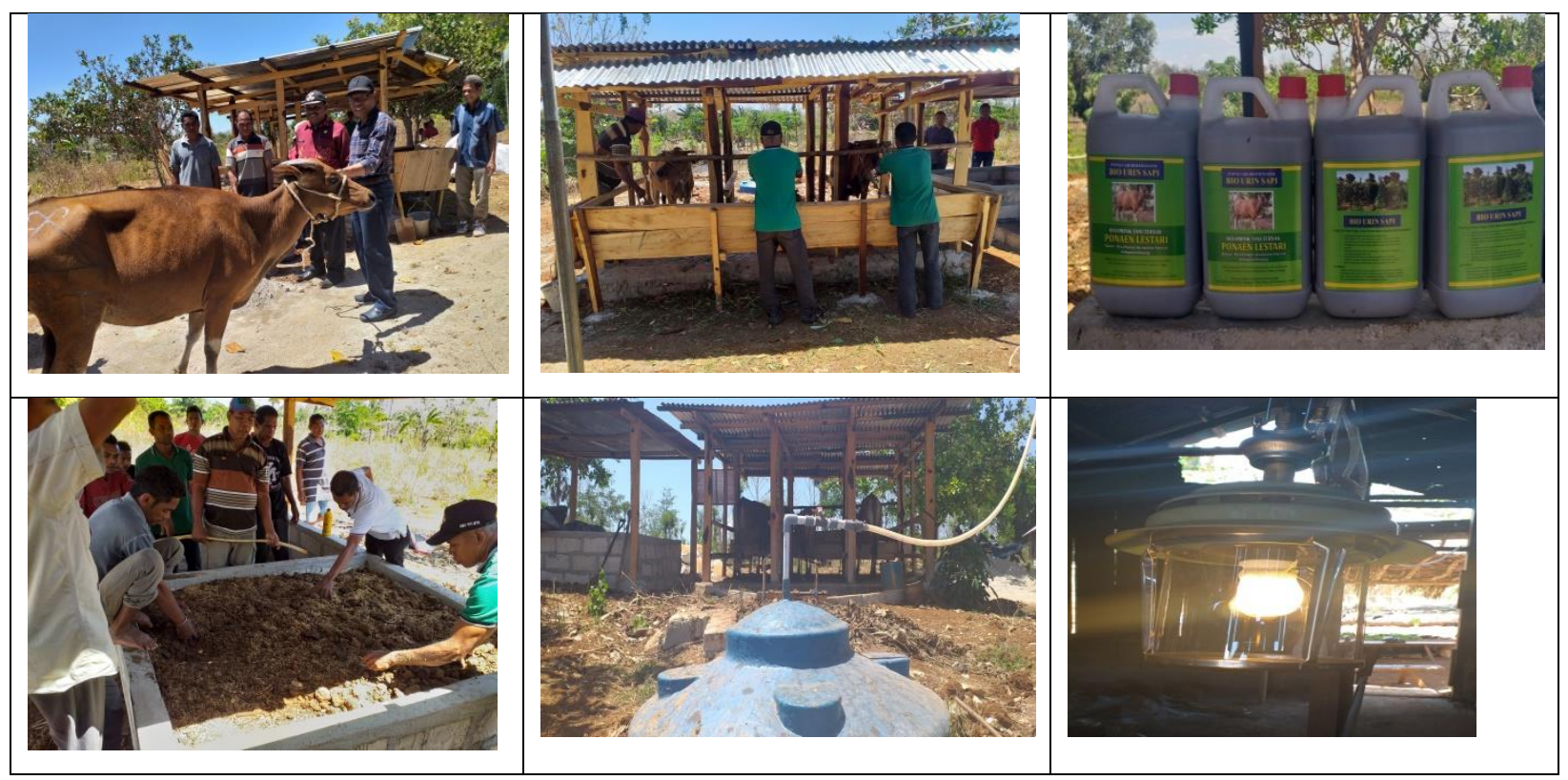

Gambar 5. Kegiatan demplot dan pendampingan pembuatan biogas dan pupuk organik pada kelompok mitra 
Pada kegiatan ini terlihat peran serta anggota kader dari mitra sasaran tergolong aktif, dapat dilihat dari keseriusan dan peran serta setiap anggota mitra dalam pembuatan demplot, mulai dari pembuatan kandang, pembuatan rumah pengolahan pupuk, desain dan istalasi biogas, serta pelatihan pembuatan pupuk organik padat (bokasih) dan pupuk cair berupa bio urin. Peran serta anggota mitra terlihat dari pembagian tugas kepada masing-masing anggota kader mitra untuk mengontrol proses instalasi biogas hingga memanfaatkan untuk penerangan dan memasak, Aktfitas mitra juga terlihat pada proses pembuatan pupuk bokasi dan juga pupuk bio urin hingga pengambilan sampel pupuk untuk dianalisis serta pengemasan dan pemanfaatan dalam usahataninya.

Tahap selanjutnya adalah melakukan pendampingan kepada masing-masing mitra dalam pemanfaatan produk. Produk yang dihasilkan oleh mitra sasaran selama kegiatan pendampingan adalah pupuk bokasih dari limbah kandang dan pupuk cair Bio Urin dari urin sapi. Kedua produk yang dihasilkan ini telah dimanfaatkan oleh anggota mitra sebagai pupuk dalam kegiatan usahatani sayuran. Dokumentasi aplikasi pupuk cair pada tanaman buncis terlihat pada gambar 6.
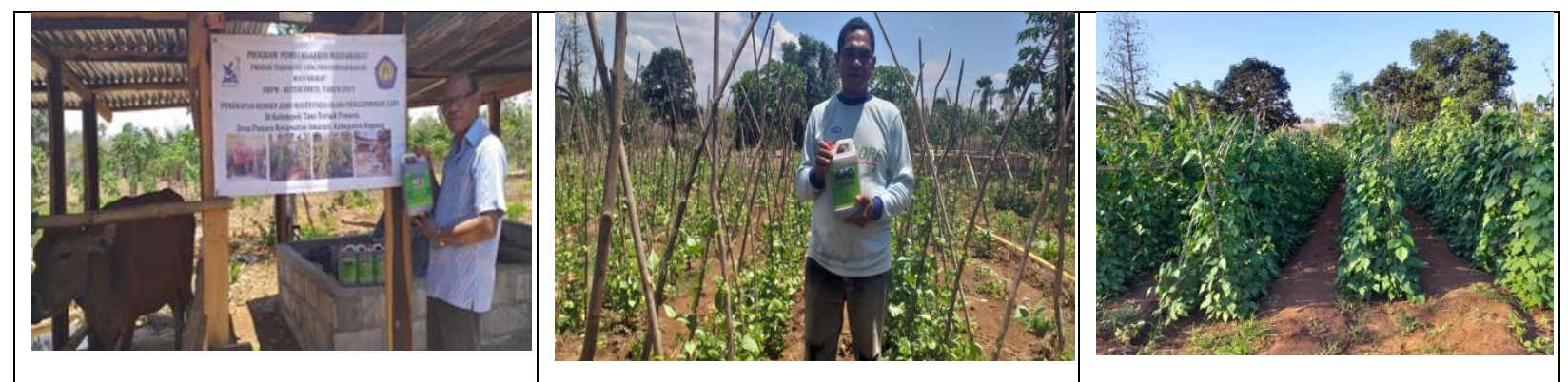

Gambar 6. Aplikasi pupuk cair Bio Urin pada tanaman kacang Buncis

Produk pupuk cair bio urin ini telah dianalisis di laboratorium. Hasil analisis diperoleh komposisi kimia pupuk cair Bio Urin (analisis berbasis kering), sebagai berikut: pH6,86, kadar C organik: 17,25 \%, Nitrogen: 2,25 \%, FosforP 0,67\% dan Kalium 1,32\%. Hasil uji coba yang dilakukan terhadap tanaman buncis menunjukkan ada pengaruh yang positif terhadap pertumbuhan tanaman, yaitu pertumbuhan tanaman lebih subur dan lebih tahan terhadap kekeringan; Hal ini menunjukkan pupuk organik cair bio urin yang dibuat sudah berfungsi dengan baik. Dengan demikian biaya untuk pemupukan dapat ditekan sehingga berdampak pada kesejahteraan anggota kelompok tani. 


\section{KESIMPULAN}

Kegiatan DPTM penerapan "Konsep Zero Waste dalam usaha penggemukan sapi di kelompok tani-ternak mitra di Desa Ponaen kecamatan Amarasi telah dilaksanakan, beberapa kesimpulan yang dapat diambil adalah :

1. Terjadi peningkatan pengetahuan anggota kelompok mitra di desa Ponaen tentang pemanfaatan limbah ternak sapi menjadi manjadi biogas pupuk organik.

2. Anggota kelompok mitra di desa Ponaen telah memiliki keterampilan dalam proses pembuatan biogas dari limbah ternak sapi dan pupuk organik (padat dan cair).

3. Produk pupuk organik cair Bio Urin yang dibuat oleh kelompok mitra, telah dianalisis dengan komposisi kimia: pH: 6,75; C-organik; 47,99\%; Nitrogen: 2,92\%; Fosfor:; 0,42\% dan Kalium: $1,26 \%$

4. Biogas hasil produk limbah ternak sapi telah dimanfaatkan untuk penerangan dan dan juga untuk memasak

5. Pupuk organik padat dan bio urin telah dimanfaatkan untuik usahatani sayuran dan berpengaruh positif terhadap tanaman buncis, sehingga dapat membantu meningkatkan pendapatan dan kesejahteraan petani/peternak.

\section{UCAPAN TERIMA KASIH}

Ucapan terimakasih disampaikan kepada Subdit Pemberdayaan Masyarakat DRPM Kemenristek

Dikti yang telah mendanai program DPTM pada tahun 2019 ini, juga kepada Pusat P2M Politeknik Pertanian Negeri Kupang yang telah memfasilitasi dan memberikan masukan sehingga kegiatan Pengabdian Kepada Masyarakat ini dapat terlaksana dengan baik

\section{DAFTAR PUSTAKA}

Yuwono, A., Nazif Ichwan, dan Satyanto Krido Saptomo. 2013. Implementasi Konsep "Zero Waste Production Management" Bidang Pertanian: Pengomposan Jerami Padi Organik Dan Pemanfaatannya. Jurnal Bumi Lestari . Volume 3 (2): 366-370 
Anonim. (2008), Membuat Pupuk Cair Bermutu dari Limbah Kambing, Warta Penelitian Dan

Pengembangan Pertanian Vol. 30 No. 6. http://pustaka.litbang.pertanian.go.id/publikasi/ wr306083.pdf, diakses 16 Oktober 2019

Matheus, R., D. Kantur, M. Basri dan M.K. Salli. 2019. Pertanian Terpadu: Model Rancang Bangun dan Penerapan pada Zona Agroekosistem Lahan Kering. Penerbit Deepublis. Yogyakarta.

Sudiarto, B. (2008). Pengelolaan Limbah Peternakan Terpadu dan Agribisnis yang Berwawasan Lingkungan, Seminar Nasional Teknologi Peternakan dan Veteriner, Bandung. 52-60.

Widjayanto, D.W., and Miyauchi, N. (2003). Organic Farming and its Prospect in Indonesia. Bull. Fac. Agric. Kagoshima Univ. 52: 57-62. 